ACTA IURIS STETINENSIS 2 (14)

DOI:10.18276/ais.2016.14-01

\title{
Radosław Zych"
}

\section{ABDICATIO HEREDITATIS IN IURE POLONIA ZRZECZENIE SIE DZIEDZICZENIA W POLSKIM PORZĄDKU PRAWNYM}

\begin{abstract}
Streszczenie
Rzymska zasada prawnicza głosi: Semel heres, semper heres, jednak zrzeczenie się dziedziczenia jest jedną z niewielu instytucji prawa spadkowego, które nie były znane w prawie rzymskim. W życiu są sytuacje, w których spadkodawca chciałby pozbawić udziałów w dziedziczeniu osobę, z którą żyje w dobrych stosunkach. Gdy nie ma podstaw do wydziedziczenia dziecka, można spróbować, przekonać je do zrzeczenia się dziedziczenia. Tematem artykułu jest zrzeczenie się dziedziczenia w polskim porządku prawnym. Autor zbada poszczególne elementy tej umowy. Spory w nim wspomniane mogą stanowić asumpt do dyskusji na temat potrzeby zmian w aktach normatywnych dotyczących problematyki badawczej.
\end{abstract}

Słowa kluczowe: prawo spadkowe, dziedziczenie, umowa, łacińska terminologia prawnicza, prawo rzymskie

dr Radosław Zych, Katedra Prawa Rzymskiego, Historii Prawa i Doktryn Polityczno-Prawnych Wydziału Prawa i Administracji Uniwersytetu Szczecińskiego; adres e-mail: radoslaw.zych@wpiaus.pl 


\section{Wprowadzenie}

Rzymska zasada prawnicza głosi: Semel heres, semper heres ${ }^{2}$, jednak zrzeczenie się dziedziczenia - obok umów dziedziczenia sensu stricto ${ }^{3}$ - jest jedną z niewielu instytucji prawa spadkowego, które nie były znane prawu rzymskiemu4. Dziedziczenie określała łacińska paremia: Hereditas nihil aliud est, quam successio in universum ius quod defunctus habuerit ${ }^{5}$. W prawie rzymskim dziedziczenie testamentowe miało pierwszeństwo przed dziedziczeniem beztestamentowym. Wykluczanie się tych dwóch porządków wyrażała zasada: Nemo pro parte testatus, pro parte intestatus decedere potest $^{6}$. $\mathrm{Z}$ uwagi na to, że wszelkie prawa i obowiązki przechodziły na spadkobiercę na skutek jednego aktu spadkobrania, dziedziczenie stanowi, tak w prawie rzymskim, jak i w prawach współczesnych, typowy przykład sukcesji uniwersalnej (successio universalis ${ }^{7}$ ).

Współcześnie zdarzają się sy tuacje życiowe, w których spadkodawca chciałby pozbawić udziałów w dziedziczeniu osobę, z którą żyje w jak najlepszych stosunkach. Na przykład jedno z dzieci - to, które już za życia zdążył wspomóc, kupił mu mieszkanie, pomógł je wyposażyć, płacił za studia. Ma jednak jeszcze młodsze dziecko i jemu chciałby zostawić po śmierci swoje mieszkanie. Aby było równo - każdemu dziecku po mieszkaniu.

W sytuacji, gdy dzieci żyją w świetnej komitywie, to starsze może obiecać, że nie będzie rościło sobie żadnych pretensji do mieszkania odziedziczonego przez młodsze. Po śmierci rodziców wiele może się jednak zmienić i obietnica

1 Z łac. - „Kto raz ustanowiony dziedzicem, zostaje nim na zawsze”. Zob. W. Bojarski, W. Dajczak, A. Sokala, Verba iuris. Reguty i kazusy prawa rzymskiego, Toruń 2007, s. 60. Zasada ta nie obowiązywała przy sporządzaniu testamentu żolnierskiego (testamentum militis). W. Wołodkiewicz, M. Zabłocka, Prawo rzymskie. Instytucje, Warszawa 2000, s. 174.

3 Bliżej na temat umów dziedziczenia w prawie rzymskim: E. Rott-Pietrzyk, Umowa dziedziczenia - uwagi de lege lata i de lege ferenda, „Rejent” 2006, nr 2, s. 162-179 i cyt. tam literatura.

4 J.S. Piątowski, Prawo spadkowe. Zarys wykładu, wyd. 4 zaktualizował i uzupełnił B. Kordasiewicz, Warszawa 2003, s. 62.

5 Z łac.- „Hereditas (dziedziczenie, spadek) jest niczym innym, jak wejściem w ogół praw, które posiadał zmarły”. A. Dębiński, Rzymskie prawo prywatne. Kompendium, Warszawa 2003, s. 335.

6 Z łac. - „Nikt nie może pozostawić dziedziców częściowo testamentowych, częściowo ustawowych". Ibidem, s.169. Od tej zasady istniały wyjątki przy testamencie żołnierskim. Współczesne kodyfikacje cywilne nie przyjęły rozwiązania prawa klasycznego. W. Wołodkiewicz, M. Zabłocka, op. cit., s. 169.

7 Ibidem, s. 168. 
nie zostanie spełniona. Gdy brak jest podstaw do wydziedziczenia dziecka, można spróbować namówić je do zrzeczenia się dziedziczenia.

\section{Konstrukcja prawna umowy}

Zasadą polskiego prawa spadkowego jest zakaz zawierania umów o spadek po osobie żyjącej ${ }^{8}$. Wyjątkiem od powyższej regulacji jest możliwość zawarcia umowy o zrzeczenie się dziedziczenia ustawowego ${ }^{9}$ między spadkobiercą ustawowym a przyszłym spadkodawcą ${ }^{10}$. Dla ważności tej umowy niezbędne jest zachowanie formy aktu notarialnego ${ }^{11}$. Ma ona charakter formy zastrzeżonej pod rygorem nieważności - ad solemnitatem ${ }^{12}$. Badaną umowę należy jednak zawrzeć polubownie, przez złożenie zgodnych oświadczeń woli. Na podpisanie umowy o zrzeczeniu się dziedziczenia muszą się zgodzić zarówno rodzice (spadkodawcy), jak i ich dziecko.

\section{Podmioty}

Podmiotami umowy mogą być przyszły spadkodawca oraz spadkobierca ustawowy. Pod pojęciem „spadkobierca ustawowy” należy rozumieć każdą osobę, która należy do kręgu spadkobierców wymienionych w ustawie, a nie tylko osobę, która byłaby powołana do spadku według stanu istniejącego w chwili zawierania umowy ${ }^{13}$. Podmiotem takiej umowy może być zatem małżonek

8 Zgodnie z art. 1047 ustawy z 23 kwietnia 1964 r. Kodeks cywilny (Dz. U. z 1964 r. nr 16, poz. 93 ze zm.) dalej cytowany jako: „k.c.”, „z zastrzeżeniem wyjątków przewidzianych w tytule niniejszym umowa o spadek po osobie żyjącej jest nieważna".

9 E. Skowrońska-Bocian, Prawo spadkowe, Warszawa 2008, s. 192.

10 Zgodnie z art. 1048 k.c. Oprócz prawa polskiego, zrzeczenie się dziedziczenia dopuszczają m.in. prawo austriackie, niemieckie i szwajcarskie. Z kolei zakaz zrzekania się dziedziczenia w drodze umowy przewiduje prawo francuskie, hiszpańskie i włoskie. Zob. A. Doliwa, Umowa o zrzeczenie się dziedziczenia, w: System Prawa Prywatnego. Tom X Prawo spadkowe, red. B. Kordasiewicz, Warszawa 2009, s. 922 i podana tam literatura.

11 Taki wymóg wynika z art. 1048 zd. 2 k.c.

12 Zgodnie z art. 73 § 2 zd. 1 k.c.

13 E. Skowrońska-Bocian, Prawo..., s. 48. 
spadkodawcy, jego zstępni, rodzice, rodzeństwo i zstępni rodzeństwa ${ }^{14}$. Stroną umowy nie może być natomiast Skarb Państwa ani gmina - podmioty te nie mogą zarzec się dziedziczenia, podobnie jak nie mogą odrzucić spadku ${ }^{15}$. Przyjęcie takiego rozwiązania należy thumaczyć celem, dla osiągnięcia którego Skarb Państwa i gmina powołane zostały w ostatniej kolejności do dziedziczenia ex lege - z założenia, że spadek nie może pozostać bez spadkobiercy ${ }^{16}$, są oni spadkobiercami koniecznymi ${ }^{17}$.

\section{Przedmiot}

Pewne trudności nasuwają się w odniesieniu do próby identyfikacji przedmiotu umowy o zrzeczenie się dziedziczenia. Przedstawiciele doktryny wyrażający pogląd, zgodnie z którym jednostce przysługuje podmiotowe prawo dziedziczenia, wskazują, że przedmiotem umowy jest właśnie to prawo. Stanowisko to jest jednak dyskusyjne.

Niewątpliwie, zrzeczenie się może dotyczyć wyłącznie dziedziczenia opartego na powołaniu z ustawy. Kodeks cywilny z 1964 roku nie przejął rozwiązania zawartego w art. 10 Prawa Spadkowego z 1946 roku$^{18}$ i nie stwarza możliwości zrzeczenia się dziedziczenia opartego na obu tytułach powołania. Umowa ta nie wyłącza zatem dziedziczenia testamentowego zrzekającego się ani możliwości wystąpienia jego $\mathrm{w}$ roli zapisobiercy ${ }^{19}$. Nasuwa się pytanie o to, czy nie należałoby

14 Nie ma zatem zastosowania zasada, w myśl której bliższy żyjący krewny wyłącza od dziedziczenia żyjącego dalszego krewnego. Zob. A. Doliwa, Umowa ..., s. 923 i podana tam literatura.

15 Wniosek taki wynika z brzmienia normy art. $1023 \S 1$ k.c.

16 E. Skowrońska-Bocian, Prawo..., s. 48. Zob. art. 935 § 3 i art. 1023 k. c.

17 Zob. A. Doliwa, Umowa..., s. 923 i podana tam literatura. Rozwiązanie takie przyjęto z uwagi na wyłączenie możliwości funkcjonowania tzw. spadków nieobjętych. Zob. J.S. Piątowski, Prawo spadkowe, Warszawa 2003, s. 62.

18 Dekret z 8 października 1946 r. - Prawo spadowe (Dz. U. nr 60, poz. 328 ze zm.). Zgodnie z ówczesnym brzmieniem normy art. $10 \S 1$, „,można w drodze umowy zawartej ze spadkodawcą zrzec się prawa do dziedziczenia”. W polskim prawie spadkowym z 1946 r. istniała możliwość zrzeczenia się dziedziczenia wynikającego zarówno z ustawy, jak i z testamentu (art. $11 \S 2$ ). Zrzekający się nie dziedziczył, chyba że został powołany do spadku na podstawie testamentu sporządzonego dopiero po zrzeczeniu się. Nie można było zatem dziedziczyć tylko na podstawie testamentu sporządzonego przed zawarciem umowy.

19 E. Rott-Pietrzyk, Umowa ..., s. 109. 
zmienić przyjętego w polskim kodeksie cywilnym rozwiązania i objąć zakresem umowy o zrzeczenie się dziedziczenia także dziedziczenia testamentowego ${ }^{20}$. Pod rządami kodeksu cywilnego zrzekający się może dziedziczyć na podstawie testamentu sporządzonego zarówno przed, jak i po zrzeczeniu się dziedziczenia. Zdaniem E. Rott-Pietrzyk warto uszanować tu zasadę swobody testowania i nie rozszerzać zrzeczenia się dziedziczenia na dziedziczenie testamentowe ${ }^{21}$. $\mathrm{Z}$ obecnej regulacji art. 1048 k.c. wynika, że umowa nie prowadzi do utraty zdolności dziedziczenia, a także nie wyłącza możliwości dziedziczenia po spadkodawcy, jako drugiej strony umowy, na podstawie powołania testamentowego ${ }^{22}$. Moim zdaniem, z uwagi na zasadę In testamentis plenius voluntates testantium interpretamur ${ }^{23}$, swoboda testowania umożliwia przyszłemu spadkodawcy sporządzenie testamentu po zrzeczeniu się dziedziczenia i powołanie w nim zrzekającego się spadkobiercy. Spadkodawca może także odwołać testament, nawet ten sporządzony przed zrzeczeniem się dziedziczenia. W świetle obowiązującego stanu prawnego nie jest możliwe zrzeczenie się spadku lub działu w spadku na rzecz innej osoby, w szczególności na rzecz innego spadkobiercy ${ }^{24}$. Pogląd taki prezentuje Sąd Najwyższy ${ }^{25}$, jednocześnie wskazując, że umowa tej treści zawarta pod rządami Dekretu z 1946 roku wywołuje skutki prawne także wtedy, gdy spadkodawca zmarł po wejściu w życie kodeksu cywilnego ${ }^{26}$.

${ }^{20}$ Ibidem.

21 Ibidem, s. 110.

22 Zob. A. Doliwa, Umowa..., s. 922 i podana tam literatura.

23 Z łac. ,przy wykładni testamentu staramy się w pełni tłumaczyć wolę testatora”. Zob. E. Gajda, B. Lubińska, Lacińska terminologia prawnicza. Ignorantia iuris nocet, Toruń 2014, s. 432.

24 Odmiennie: art. 13 Dekretu - Prawo spadkowe. Zgodnie z ówczesnym brzmieniem normy art. 13, „,zrzeczenie się prawa dziedziczenia na korzyść innej osoby uważa się w razie wątpliwości za zrzeczenie się pod warunkiem, że osoba ta będzie dziedziczyć".

25 Postanowienie SN z 20 maja 1984 r., sygn. III CRN 35/84, OSN 1984, nr 10, poz. 184.

26 Uchwała SN z 5 lutego 1993 r., sygn. III CZP 10/93, OSNC 1993, nr 9, poz. 147 z glosą E. Skowrońskiej, OSP 1994, nr 5, poz. 83. 


\section{Skutki}

Skutki prawne związane z zawarciem umowy o zrzeczenie się dziedziczenia powstaną dopiero $\mathrm{z}$ chwilą otwarcia spadku ${ }^{27}$. Zgodnie $\mathrm{z}$ art. 1049 $\S 1$ k.c., ,zrzeczenie się dziedziczenia obejmuje również zstępnych zrzekającego się, chyba że umówiono się inaczej”. Umowa o zrzeczeniu się dziedziczenia rozciąga się też na zstępnych, czyli dzieci, wnuki, prawnuki osoby zrzekającej się dziedziczenia. Przywołana wyżej norma prawna jest jednak przykładem ius dispositivum, zatem prawo dopuszcza możliwość zawarcia umowy ze skutkiem jedynie dla zrzekającego się, a tym samym - z wyłączeniem jego zstępnych. Konstrukcja prawna badanej umowy dopuszcza możliwość wywołania jej skutków jedynie do niektórych wyraźnie wskazanych zstępnych zrzekającego się ${ }^{28}$. Natomiast w sytuacji, gdy stroną umowy jest jedynie spadkobierca ustawowy zrzekający się dziedziczenia, to zstępni nie mają wpływu na treść składanego oświadczenia woli ${ }^{29}$.

Po podpisaniu umowy dziecko zrzekającego się spadku będzie traktowane w procesie dziedziczenia tak, jakby się nigdy nie urodziło. Na podstawie art. 1049 § 2 k.c., ,zrzekający się oraz jego zstępni, których obejmuje zrzeczenie się dziedziczenia, zostają wyłączeni od dziedziczenia tak, jakby nie dożyli otwarcia spadku". Trochę to nieprzyjemne, ale przecież rodzice dbają o to dziecko, wciąż mu pomagają i będą to robić aż do śmierci. Chcą też jednak zabezpieczyć drugie dziecko. Umowa o zrzeczenie się dziedziczenia skutkująca uznaniem zrzekającego się za takiego, „który nie dożył otwarcia spadku” jest sposobem na uniknięcie

${ }^{27}$ Zob. A. Doliwa, Umowa..., s. 923 i podana tam literatura. Właśnie ten aspekt jest jednym z kryteriów odróżniających umowę o zrzeczeniu się dziedziczenia od odrzucenia spadku. Zrzeczenie się dziedziczenia jest umową zawartą przed otwarciem spadku, za życia przyszłego spadkodawcy. Ponadto, przy ustalaniu udziału spadkowego, stanowiącego podstawę obliczania należnego zachowku, nie uwzględnia się spadkobierców, którzy zrzekli się spadku ani zstępnych spadkobiercy ustawowego, zaś uwzględnia się tych spadkobierców, którzy spadek odrzucili. Ibidem, s. 924.

28 A. Doliwa, Umowa..., s. 928 i podana tam literatura.

29 Ponieważ zrzeczenie się dziedziczenia traktowane jest jako osobiste uprawnienie spadkobiercy ustawowego, niedopuszczalna jest jakakolwiek ingerencja w treść oświadczenia woli, a także weryfikacja lub ocena zasadności motywów i pobudek zrzeczenia się dziedziczenia przez osoby trzecie. A. Doliwa, Umowa ..., s. 928 i podana tam literatura. 
konieczności wypłacenia zachowku ${ }^{30}$. Osobę, która zrzekła się dziedziczenia, traktuje się tak, jakby nie dożyła otwarcia spadku - nie uczestniczy ona w podziale majątku.

Osoba, która zrzekła się dziedziczenia, może dziedziczyć na podstawie testamentu - niezależnie od tego, czy testament sporządzony został przed, czy po zawarciu umowy ${ }^{31}$. Zrzeczenie się dziedziczenia nie czyni także bezskutecznym zapisu uczynionego przez spadkodawcę na rzecz zrzekającego się ${ }^{32}$. Co istotne, umowa o zrzeczenie się dziedziczenia jest skuteczna bez względu na to, jak długi czas upłynął między chwilą jej zawarcia, a datą śmierci spadkodawcy - strony umowy ${ }^{33}$.

\section{Możliwość odwołania umowy}

Umowa ta nie podlega jednostronnemu odwołaniu, cojest dobrym rozwiązaniem dla drugiego dziecka. Jego brat/siostra nie będą mogli po śmierci rodziców stwierdzić, że się rozmyślili, zmienili zdanie i jednak chcą dziedziczyć. Skutki zrzeczenia się dziedziczenia mogą zostać zniweczone w drodze ich umownego uchylenia. Umowa stosownej treści musi zostać sporządzona w formie aktu notarialnego między tym, kto zrzekł się dziedziczenia, a tym, po kim dziedziczenia się zrzeczono ${ }^{34}$. Umowę tę zawiera spadkodawca i spadkobierca ustawowy będący stroną umowy, a w razie jego śmierci - zstępny lub zstępni, na których rozciągają się jej skutki ${ }^{35}$. Dopuszczalne jest

${ }_{30} \mathrm{Z}$ art. $991 \S 1$ k.c. wynika bowiem, że uprawnionym do zachowku jest ten, kto w przypadku braku testamentu dziedziczyłby z ustawy. W przypadku, gdy zachodzi przyczyna wydziedziczenia, umowa o zrzeczenie się dziedziczenia jest dobrym instrumentem do pozbawienia spadkobiercy ustawowego prawa do zachowku. Daje ona gwarancję spadkodawcy, że spadkobierca ustawowy po śmierci spadkodawcy nie będzie miał możliwości skutecznego podniesienia roszczeń o zachowek. Niezmiernie trudne, wręcz niemożliwe dla spadkobiercy, jest bowiem obalenie umowy zawartej przez niego ze spadkodawcą w formie aktu notarialnego. W praktyce prostsze jest wykazanie przez wydziedziczonego spadkobiercę braku przyczyny wydziedziczenia. Zob. E. Rott-Pietrzyk, Umowa, s. 112-113.

31 Zob. Uchwała SN z 15 maja 1972 r., sygn. III CZP 26/72, OSN 1972, nr 11, poz. 197; E. Skowrońska, Z problematyki powołania spadkobiercy w testamencie, „Palestra” 1993, nr 1-2, s. 7 i nast.

32 E. Skowrońska-Bocian, Prawo..., s. 48.

33 Tak E. Niezbecka, Prawo spadkowe, Lublin 2000, s. 153.

34 Zgodnie $\mathrm{z}$ art. 1050 k.c.

35 Tak. M. Pazdan, w: Kodeks cywilny, t. II, Komentarz do art. 450-1088, red. K. Pietrzykowski, Warszawa 2005, s. 1110. 
także zawarcie umowy zmieniającej zrzeczenie się dziedziczenia (argument a maiori ad minus ${ }^{36}$ ), m.in. przez wyłączenie skutków zrzeczenia się względem zstępnych zrzekającego się i na odwrót. Nie można natomiast częściowo uchylić zrzeczenia się dziedziczenia ${ }^{37}$. Warto dodać, że sporządzenie przez spadkodawcę testamentu, w którym powoła on do dziedziczenia zrzekającą się osobę nie przywraca statusu spadkobiercy ustawowego, a tym samym - prawa do zachowku ${ }^{38}$.

\section{Problemy klasyfikacyjne}

Umowy o zrzeczenie się dziedziczenia nie należy obejmować zakresem pojęcia „rozrządzenie ostatniej woli”, chociaż wywołuje skutki prawne w chwili śmierci spadkodawcy. Biorąc pod uwagę moment wystąpienia skutków tej czynności, jest ona czynnością mortis causa ${ }^{39}$, tyle że istotna jest tu nie śmierć zrzekającego się, lecz osoby, wobec której zrzeczenie się następuje ${ }^{40}$. Problem charakteru prawnego instytucji umownego zrzeczenia się dziedziczenia nie jest jednoznacznie w doktrynie prawa spadkowego rozstrzygnięty ${ }^{41}$. Zrzeczenie się dziedziczenia nie jest zaliczane do czynności prawnych zobowiązujących ${ }^{42}$, rozporządzających ${ }^{43}$ ani też

36 Ibidem.

37 Zob. A. Doliwa, Umowa..., s. 933 i podana tam literatura.

38 Ibidem, s. 933.

39 Tak Z. Radwański, w: System prawa prywatnego, t. II, red. Z. Radwański, Warszawa 2002, s. 217.

40 Tak M. Pazdan, w: Kodeks cywilny..., s. 1105; M. Niedośpiał, Swoboda testowania, Bielsko-Biała 2004, s. 17-18.

41 Zob. A. Doliwa, Umowa..., s. 925 i podana tam literatura.

42 Umowa z art. 1048 k.c. nie jest umową obligacyjną, ponieważ jej skutki nie polegają tylko na powstaniu po stronie spadkobiercy ustawowego zobowiązania (do zrzeczenia się dziedziczenia), którego realizacja wyłączy go od dziedziczenia (np. przez odrzucenie spadku). Zob. A. Doliwa, Umowa..., s. 925.

43 Zdaniem M. Pazdana z pozycji zrzekającego się umowa o zrzeczenie się dziedziczenia jest jednak czynnością prawną podobną do czynności prawnych rozporządzających; M. Pazdan, Umowa o zrzeczenie się dziedziczenia w polskim prawie spadkowym, „Rejent” 1997, nr 4, s. 184; Idem, w: Kodeks cywilny..., s. 1105. Zdaniem A. Doliwy, umowa ta nie jest typową czynnością prawną rozporządzającą, gdyż jej skutkiem bezpośrednim nie jest przeniesienie, obciążenie albo zniesienie majątkowego prawa podmiotowego. Zob. A. Doliwa, Prawo spadkowe, Warszawa 2007, s. 17. 
przysparzających ${ }^{44}$. Czynność ta nie ma charakteru osobistego, a zatem każda ze stron może posłużyć się pełnomocnikiem ${ }^{45}$. Zrzec się dziedziczenia w drodze umowy z art. 1048 k.c. można tylko za życia przyszłego spadkodawcy, umowa zawarta po śmierci mocodawcy-spadkodawcy będzie umową nieważną ${ }^{46}$. Umowa ta nie jest umową odpłatną, a tym bardziej wzajemną, nawet wówczas gdy zrzeczeniu się dziedziczenia towarzyszy przysporzenie na rzecz zrzekającego się ${ }^{47}$. W razie braku jakiegokolwiek przysporzenia jako rekompensaty za zrzeczenie się dziedziczenia umowa nie ma charakteru darowizny ${ }^{48}$. Ponadto umowy takiej nie można traktować jako czynności prawnej zobowiązującej potencjalnego spadkobiercę (zrzekającego się dziedziczenia) do odrzucenia spadku ${ }^{49}$.

Umowę zrzeczenia się dziedziczenia muszą zatem odwołać obie strony. Rodzice i ich starsze dziecko mogliby to zrobić np. wtedy, gdyby okazało się, że młodsze dziecko zmarło przedwcześnie, przed rodzicami, i nie będzie mogło odziedziczyć ich mieszkania. Może przydarzyć się także i taka sytuacja, w której młodsze dziecko znajdzie sobie bogatego partnera i nie będzie potrzebowało mieszkania rodziców. Może też drastycznie zmienić się jego postępowanie wyrzeknie się rodziny, zerwie z nią wszelkie kontakty, nie będzie opiekowało się rodzicami w potrzebie. Każdy z tych wypadków może być dla rodziców pretekstem do odwołania umowy zrzeczenia się dziedziczenia ${ }^{50}$. Chodzi o to, aby mieszkanie po ich śmierci nie przepadło.

${ }^{44}$ Bliżej odnośnie do spornego charakteru prawnego umowy o zrzeczenie się dziedziczenia zob. M. Pazdan, w: Kodeks cywilny...

45 Do dokonania tej czynności prawnej nie wystarcza jednak udzielenie pełnomocnictwa ogólnego. Forma pełnomocnictwa powinna czynić zadość wymogom wynikającym z art. 99 $\S 1$ k.c. w zw. z art. 1048 k.c. Zob. A. Doliwa, Umowa ..., s. 923-924 i podana tam literatura.

46 Argument z art. 58 § 1 k.c. w zw. z art. 1048 i 1047 k.c.. Zob. A. Doliwa, Umowa ..., s. 922 i podana tam literatura.

47 Tak J.S. Piątowski, Prawo spadkowe. Zarys wykładu, Warszawa 1973, s. 62; A. Oleszko, Umowy dotyczace spadku w praktyce notarialnej, „Nowe Prawo” 1977, nr 3, s. 841-842; J. Kosik, System prawa cywilnego, t. IV: Prawo spadkowe, red. J. S. Piątowski, Wrocław-WarszawaKraków-Gdańsk-Łódź 1986, s. 585; M. Pazdan, Umowa o zrzeczenie się dziedziczenia ..., s. 184.

48 M. Pazdan, Umowa o zrzeczenie się dziedziczenia..., s. 183, 184; Idem, w: Kodeks cywilny..., s. 1105.

49 Zob. A. Doliwa, Umowa..., s. 925.

50 Szerzej o umowie zrzeczenia się dziedziczenia: J. Kozak, Umowa zrzeczenia się dziedziczenia, „Przegląd Sądowy” 2004, nr 11-12; E. Rott-Pietrzyk, Umowa o zrzeczenie się dziedziczenia - uwagi de lege lata i de lege ferenda, „Rejent” 2006, z. 3. 


\section{Zastosowanie umowy o zrzeczenie się dziedziczenia w praktyce}

Z badań dotyczących wykorzystania umów zrzeczenia się dziedziczenia wynika, że jest ona instrumentem potrzebnym, użytecznym i wykorzystywanym w praktyce notarialnej ${ }^{51}$. Pozytywną funkcją jest powiązanie jej z dokonaniem przysporzeń na rzecz określonych osób. Praktyka notarialna wskazuje, że najczęściej zawierane są między tymi samymi stronami dwie oddzielne umowy w formie aktu notarialnego: umowa darowizny, a następnie umowa o zrzeczenie się dziedziczenia. Nie ma przeszkód, aby oświadczenia woli stron, dotyczące obu umów, zostały objęte jednym aktem notarialnym ${ }^{52}$. W praktyce obrotu zrzeczenie się dziedziczenia towarzyszy często innej umowie zawartej między tymi samymi stronami, umową tą może być nie tylko darowizna, ale i majątkowa umowa małżeńska. Praktyka zastosowania tej umowy pozwala na skuteczne rozszerzenie swobody testowania, szczególnie w sytuacji, gdy spadkodawca z jednej strony ma spadkobierców ustawowych, co do których brakuje przyczyn wydziedziczenia, a z drugiej zamierza rozrządzić całym majątkiem na rzecz osoby pozostającej poza kręgiem jego spadkobierców.

\section{Spory wokół umowy o zrzeczenie się dziedziczenia}

Zasygnalizowany wyżej problem, dotyczący uznania umowy o zrzeczenie się dziedziczenia jako czynności prawnych rozporządzających, moim zdaniem, pozwala na zastosowanie per analogiam art. 17 k.c. w kwestii ustalenia zdolności do jej zawarcia. Co do zasady, zrzekający się dziedziczenia musi mieć pełną zdolność do czynności prawnych, ponieważ zrzeka się spadku. Natomiast, stosownie do art. 17 k.c. a contrario, druga strona umowy - spadkodawca, może zawrzeć umowę o zrzeczenie się dziedziczenia, nawet jeśli ma ograniczoną

51 Zob. E. Pietrzyk, Umowa..., s. 111-112.

${ }^{52} \mathrm{~W}$ takim przypadku przyjmuje się, że w razie równoczesnego zawarcia umowy zrzeczenia się dziedziczenia i umowy darowizny (na rzecz zrzekającego się) zrzeczenie nie stanowi przyczyny prawnej (causa) darowizny. A. Doliwa, Umowa..., s. 926 i podana tam literatura. Charakteryzowana umowa jest samodzielną i odrębną czynnością prawną i musi być oceniana w świetle art. 1048 in. k.c. Zob. ibidem, s. 927 i podana tam literatura. 
zdolność do czynności prawnych ${ }^{53}$. Jednak, moim zdaniem, nie należy stosować per analogiam art. 899 §1 k.c. czy art. 930 §1 k.c. ${ }^{54}$, gdyż w odniesieniu do badanej umowy jedyną prawnie dopuszczalną możliwością jej odwołania jest zawarcie nowej umowy, także w formie aktu notarialnego.

Problemy zasygnalizowane powyżej świadczą o tym, że z treścią umowy o zrzeczenie się dziedziczenia wiąże się wiele kwestii spornych. Chodzi w szczególności o dopuszczalność warunku zrzeczenia się dziedziczenia na korzyść określonej osoby, dopuszczalność częściowego zrzeczenia się dziedziczenia, ograniczonego np. do ułamkowej części spadku, mającego przypaść zrzekającemu się spadkobiercy na podstawie dziedziczenia ustawowego, a także dopuszczalność zrzeczenia się jedynie prawa do zachowku ${ }^{55}$.

Zwolennicy tezy o niedopuszczalności zrzeczenia się dziedziczenia na korzyść określonej osoby odwołują się do argumentu, że nie wprowadzono do obowiązującego kodeksu cywilnego regulacji wzorowanej na art. 13 Prawa spadkowego z 1946 roku $^{56}$. Sąd Najwyższy ${ }^{57}$ opowiedział się tymczasem za dopuszczalnością zawierania pod rządem kodeksu cywilnego umów o zrzeczenie się dziedziczenia na korzyść innej osoby. W przywołanym orzeczeniu, Sąd podkreślił „cele utylitarne umowy o zrzeczenie się dziedziczenia”, zwrócił również uwagę, że „chociaż umowa ta nie została normatywnie powiązana z innymi umowami, to jednak w obrocie występuje ona powszechnie w ścisłym zespoleniu z darowizną; zrzeczenie jest wówczas aktem obdarowanego, rezygnującego w następstwie przysporzenia z ekspektatywy nabycia spadku po darczyńcy". Układ rodzinny lub sytuacja majątkowa stwarzają przy tym potrzebę (moralną

53 Spadkobierca, który nie ma pełnej zdolności do czynności prawnych, musi działać przy udziale przedstawiciela ustawowego, za zgodą sądu opiekuńczego. Zob. art. 14 § 1 k.c., art. 98 $\S 1$, art. $101 \S 3$, art. $155,156,178 \S 2$ ustawy z 25 lutego 1964 r. - Kodeks rodzinny i opiekuńczy (Dz. U. z 1964 r. nr 9, poz. 59 ze zm.). Zob. A. Doliwa, Umowa..., s. 923 i podana tam literatura.

54 Przywołane normy prawne odnoszą się do skutków przebaczenia. Należy jednak przyjąć, że ustalenie konsekwencji złożenia oświadczenia woli o uchyleniu się od jego skutków jako złożonego pod wpływem błędu lub podstępu należy do sądu, przed którym toczy się postępowanie o stwierdzenie nabycia spadku. Zob. A. Doliwa, Umowa ..., s. 933 i podana tam literatura.

55 Problemy te identyfikuje E. Rott-Pietrzyk, Umowa..., s. 113-118 i podana tam literatura.

56 Ibidem, s. 114-115.

57 Uchwała SN z 5 lutego 1993 r., sygn. III CZP 10/93, OSNCP 1993, nr 9, poz. 147 z glosą E. Skowrońskiej, OSP 1994, nr 5, poz. 83, s. 217, aprobującą tezę uchwały, krytyczną w odniesieniu do fragmentu uzasadnienia dotyczącego możliwości zawarcia umowy o zrzeczeniu się dziedziczenia na korzyść innej osoby. 
powinność) zrzeczenia się dziedziczenia na rzecz innego spadkobiercy, co daje kontrahentom poczucie sprawiedliwości i stabilizacji, zapobiega także ewentualnym sporom w dziale spadku, szczególnie przy zaliczaniu na schedę spadkową otrzymanych darowizn.

W piśmiennictwie zwrócono uwagę, że badana umowa nie stanowi prawdziwego pactum in favorem tertii z art. 393 §1 k.c. ${ }^{58}$ Wyrażono opinię, że należy dopuścić możliwość uzależnienia skuteczności zrzeczenia się dziedziczenia od warunku polegającego na powołaniu do dziedziczenia w chwili otwarcia spadku określonej osoby na podstawie ustawy lub testamentu ${ }^{59}$. Jednocześnie podkreślano, że umowa ta, podobnie jak umowa dziedziczenia sensu stricto, nie może stanowić tytułu powołania do dziedziczenia ${ }^{60}$ (art. 941 w zw. z art. 1047 k.c.). Umowę o zrzeczenie się dziedziczenia określa się jako dopuszczalny przez ustawę „negatywny kontrakt dziedziczenia", nieustanawiający tytułu powołania do dziedziczenia ${ }^{61}$.

Odnosząc się do problemu dopuszczalności częściowego zrzeczenia się dziedziczenia, uznano je za „rozsądne i słuszne” z uwagi na ważne funkcje, które takie zrzeczenie ma spełniać w praktyce ${ }^{62}$.

Umowa o zrzeczenie się dziedziczenia odgrywa istotną rolę w zakresie wpływania spadkobiercy na losy majątku po jego śmierci ${ }^{63}$. Niewątpliwie analiza brzmienia norm prawnych art. 1048-1050 k.c., a nadto reguła interpretacyjna a maiori ad minus, moim zdaniem, przesądza o możliwości zrzeczenia się dziedziczenia ograniczonego do ułamkowej części spadku (udziału w spadku) - tym bardziej, że ex lege możliwe jest zrzeczenie się całości dziedziczenia.

Stosując podobną argumentację, można opowiedzieć się za dopuszczalnością zrzeczenia się jedynie prawa do zachowku. W sytuacji, gdyby uprawnionemu do zachowku należałby się zachowek o wartości znacznie przewyższającej

58 E. Rott-Pietrzyk, Umowa ... i podana tam literatura, s. 116. Zob. A. Doliwa, Umowa ..., s. 932.

59 Tak M. Pazdan, w: Kodeks cywilny..., s. 1107; podobnie A. Doliwa, Umowa ..., s. 927 i podana tam literatura.

60 Tak M. Pazdan, w: Kodeks cywilny..., s. 1107; por. Wyrok SN z 20 marca 1984 r., sygn. III CRN 35/84, OSNCP 1984, nr 10, poz. 184.

${ }_{61}$ Zob. A. Doliwa, Umowa..., s. 922 i podana tam literatura.

62 E. Rott-Pietrzyk, Umowa..., s. 117 i podana tam literatura.

${ }^{63}$ Ibidem, s. 106. Choć pogląd ten w doktrynie został podważony, wskazano, że umowa ta „służy określeniu składu przyszłego spadku po zrzekającym się dziedziczenia ustawowego”, nie stanowiąc rozrządzenia ostatniej woli ze strony przyszłego spadkodawcy. Zob. A. Doliwa, Umowa..., s. 926-927 i podana tam literatura. 
wartość uzyskanego przez niego na podstawie dziedziczenia ustawowego lub testamentowego majątku ${ }^{64}$, zrzeczenie się jedynie prawa do zachowku nie pozbawia osoby zrzekającej się pozycji spadkobiercy ${ }^{65}$.

\section{Podsumowanie}

Jedną z zasad polskiego prawa cywilnego jest autonomia woli jego podmiotów, realizację tej wartości (plenum voluntas) umożliwia także zawarcie umowy o zrzeczenie się dziedziczenia, która pozwala chronić inne dobra, np. poczucie sprawiedliwości (suum cuique tribuere ${ }^{66}$ ) w rodzinie w sytuacji, gdy spadkodawca wyposażył już za życia jedno bądź niektóre z dzieci. Charakteryzowana umowa służy zatem określeniu składu przyszłego spadku po zrzekającym się dziedziczenia ustawowego. Kwestie sporne zarysowane w końcowej części rozważań mogą stanowić asumpt do dyskusji nad potrzebą zmian regulacji normatywnych w zakresie badanej problematyki. Niebagatelnego znaczenia nabiera orzecznictwo sądowe - dla przykładu, Sąd Najwyższy w prezentowanej już uchwale z 5 lutego 1993 roku uznał dopuszczalność zastrzegania warunku przy umowach o zrzeczenie się dziedziczenia oraz dopuszczalność zawierania tego typu umów na korzyść określonej osoby.

Niewątpliwie umowa o zrzeczenie się dziedziczenia zajmuje ugruntowaną pozycję w polskiej praktyce notarialnej i świadomości społecznej. Polskie prawo dopuszcza możliwość zawarcia umowy ze skutkiem jedynie dla zrzekającego się, a tym samym - z wyłączeniem jego zstępnych, a zatem lex est quod notamus ${ }^{67}$. Ta łacińska paremia prawnicza podkreślać ma rolę notariuszy w polskim porządku

${ }^{64}$ Tak M. Pazdan, w: Kodeks cywilny..., s. 1108.

${ }^{65}$ E. Rott-Pietrzyk, Umowa..., s. 118 i podana tam literatura. Zrzekający się jedynie prawa do spadku nie może być traktowany tak, jakby nie dożył otwarcia spadku. Zob. A. Doliwa, Umowa..., s. 930 i podana tam literatura.

${ }^{66}$ Fragment $\mathrm{z}$ łacińskiej paremii prawniczej, nakazującej „każdemu oddać to, co mu się należy”. Zob. E. Gajda, B. Lubińska, op. cit., s. 162.

67 Z łac. - prawem jest to, co piszemy. Zob. Lingua Latina, http://lingua-latina.go-longhorn. net/sentencja,opis,1493964,124497.html (15.11.2015). Przywołana łacińska premia prawnicza zdobi stronę internetową Stowarzyszenia Notariuszy Rzeczypospolitej Polskiej. Zob. http://www. rejent.com.pl/ ( 15.11.2015). Została umieszczona w Pierwszym Edykcie Cesarskim Stanowiącym Prawo Miłościwie Panującego Cesarza Salima Rogera IV El Suf de Eghezee w Pałacu Cesarskim w Cyncie, dnia 11 czerwca 1244 r. Zob. http://www.kruk.ayz.pl/cesarstwo/Edykt1.pdf(15.11.2015). 
prawnym, bowiem notariusz jest powołany do dokonywania czynności, którym strony są obowiązane lub pragną nadać formę notarialną, działając w tym zakresie jako osoba zaufania publicznego ${ }^{68}$. Potrzebę znajomości łacińskiej terminologii prawniczej podkreślają przedstawiciele polskiej romanistyki. Dla przykładu, Witold Warkałlo zwracał uwagę na konieczność znajomości łaciny pośród prawników ${ }^{69}$. Z kolei Witold Wołodkiewicz ut eleganter dicit ,prawnik, który poznałby tylko prawa swego kraju i nie nauczyłby się prawa rzymskiego, pozostałby na całe życie człowiekiem powierzchownym. Wydaje nam się zresztą, że ktoś taki w ogóle nie byłby prawnikiem, lecz tylko miernym praktykiem prawa"70.

\section{Literatura}

Bojarski W., Dajczak W., Sokala A., Verba iuris. Reguty i kazusy prawa rzymskiego, Toruń 2007.

Dębiński A., Rzymskie prawo prywatne. Kompendium, Warszawa 2003.

Doliwa A., Prawo spadkowe, Warszawa 2007.

Doliwa A., Umowa o zrzeczenie się dziedziczenia, w: System Prawa Prywatnego. Tom X Prawo spadkowe, red. B. Kordasiewicz, Warszawa 2009.

Gajda E., Lubińska B., Lacińska terminologia prawnicza. Ignorantia iuris nocet, Toruń 2014.

Kosik J., System prawa cywilnego, T. IV, w: Prawo spadkowe, red. J. S. Piątowski, Wrocław-Warszawa-Kraków-Gdańsk- - Łódź 1986.

Kozak J., Umowa zrzeczenia się dziedziczenia, „Przegląd Sądowy” 2004, nr 11-12.

Niedośpiał M., Swoboda testowania, Bielsko-Biała 2004.

Niezbecka E., Prawo spadkowe, Lublin 2000.

Oleszko A., Umowy dotyczace spadku w praktyce notarialnej, „Nowe Prawo” 1977, nr 3. Pazdan M., Umowa o zrzeczenie się dziedziczenia w polskim prawie spadkowym, „Rejent” 1997, nr 4.

Pazdan M, w: Kodeks cywilny, T. II, Komentarz do art. 450-1088, red. K. Pietrzykowski, Warszawa 2005.

68 Zob. art. $1 \S 1$ i art. 2 § 1 ustawy z 14 lutego 1991 r. - Prawo o notariacie (Dz. U. nr 22, poz. 91 ze zm.).

${ }^{69}$ A. Sokala, Witold Warkatto (1909-1983), w: Quinque Doctores. Kierownicy Katedry Prawa Rzymskiego UMK (1945-2000), pod red. A. Sokali, W. Mossakowskiego, E. Gajdy, Toruń 2014, s. 59.

70 W. Wołodkiewicz, Prawoznawstwo w pogladach i ujęciu Encyklopedystów, Warszawa 1990, s. 181. 
Piątowski J.S., Prawo spadkowe. Zarys wykładu, Warszawa 1973.

Piątowski J.S., Prawo spadkowe. Zarys wykładu, wyd. 4 zaktualizował i uzupełnił B. Kordasiewicz, Warszawa 2003.

Radwański Z., w: System prawa prywatnego, T. II, red. Z. Radwański, Warszawa 2002. Rott-Pietrzyk E., Umowa dziedziczenia - uwagi de lege lata i de lege ferenda, „Rejent” 2006, nr 3 (179).

Skowrońska-Bocian E., Prawo spadkowe, Warszawa 2008.

Sokala A., Witold Warkałto (1909-1983), w: Quinque Doctores. Kierownicy Katedry Prawa Rzymskiego UMK (1945-2000), pod red. A. Sokali, Toruń 2014.

Wołodkiewicz W., Prawoznawstwo w poglądach i ujęciu Encyklopedystów, Warszawa 1990.

Wołodkiewicz W., Zabłocka M., Prawo rzymskie. Instytucje, Warszawa 2000.

\section{Akty normatywne}

Dekret z 8 października 1946 r. - Prawo spadowe (Dz. U. nr 60, poz. 328 ze zm.).

Ustawa z 23 kwietnia 1964 r. - Kodeks cywilny (Dz. U. z 1964 r. nr 16, poz. 93 ze zm.).

Ustawa z 25 lutego 1964 r. - Kodeks rodzinny i opiekuńczy (Dz. U. z 1964 r. nr 9, poz. 59 ze zm.).

Ustawa z 14 lutego 1991 r. - Prawo o notariacie (Dz. U. nr 22, poz. 91 ze zm.).

\section{Orzecznictwo}

Wyrok SN z 20 marca 1984 r., sygn. III CRN 35/84, OSNCP 1984, nr 10, poz. 184.

Postanowienie SN z 20 maja 1984 r., sygn. III CRN 35/84, OSN 1984, nr 10, poz. 184.

Uchwała SN z 5 lutego 1993 r., sygn. III CZP 10/93, OSNC 1993, nr 9, poz. 147, OSP 1994, nr 5, poz. 83.

\section{Strony internetowe}

Lingua Latina, http://lingua-latina.go-longhorn.net/sentencja,opis,1493964,124497.html (15.11.2015).

Pierwszy Edykt Cesarski Stanowiący Prawo Miłościwie Panującego Cesarza Salima Rogera IV El Suf de Eghezee sporządzony w Pałacu Cesarskim w Cyncie, dnia 11 czerwca 1244 r., http://www.kruk.ayz.pl/cesarstwo/Edykt1.pdf (15.11.2015).

Stowarzyszenie Notariuszy Rzeczypospolitej Polskiej, http://www.rejent.com.pl/ (15.11.2015). 


\section{ABDICATIO HEREDITATIS IN IURE POLONIA RENUNCIATION OF INHERITANCE IN POLISH LEGAL ORDER}

According to the Roman legal principle: "Semel heres semper heres". However, the renunciation of inheritance is one of the few institutions of inheritance law, which were not known in Roman law. There are situations in life in which the testator would like to deprive the shares in the inheritance a person with whom he lives in the best possible relations. When there are no grounds for disinheritance of the child, you can try to persuade them to renounce their inheritance. This article is about renunciation of inheritance in Polish legal order. The author will examine in this article the individual elements constructing this agreement. Disputes outlined in considerations may be helped for a discussion on the need for changes in normative regulations on research issues.

Keywords: agreement, inheritance, Linqua Latina, Polish legal order, renunciation, Roman Law. 